Article

\title{
Suppressive Effect of Arctium lappa L. Leaves on Retinal Damage against A2E-Induced ARPE-19 Cells and Mice
}

\author{
Dong Hee Kim ${ }^{1,2}$, Yae Rim Choi ${ }^{1,3}$, Jaewon Shim ${ }^{1}$, Yun-Sang Choi ${ }^{4}{ }^{\circ}$, Yun Tai Kim ${ }^{1,5}{ }^{\oplus}$, \\ Mina Kyungmin Kim ${ }^{2}$ and Min Jung Kim ${ }^{1, *}$ \\ 1 Research Division of Food Functionality, Korea Food Research Institute, Wanju 55365, Korea; \\ donghey543@naver.com (D.H.K.); uiu7895@naver.com (Y.R.C.); jwshim@kfri.re.kr (J.S.); \\ ytkim@kfri.re.kr (Y.T.K.) \\ 2 Department of Food Science and Human Nutrition, Jeonbuk National University, Jeonju-si 54896, Korea; \\ minakim@jbnu.ac.kr \\ 3 Department of Food Science and Engineering, Ewha Womans University, Seoul 03760, Korea \\ 4 Research Division of Strategic Food Technology, Korea Food Research Institute, Wanju 55365, Korea; \\ kcys0517@kfri.re.kr \\ 5 Department of Food Biotechnology, Korea University of Science \& Technology, Daejeon 34113, Korea \\ * Correspondence: mjkim14@kfri.re.kr; Tel.: +82-63-219-9380
}

Received: 18 March 2020; Accepted: 8 April 2020; Published: 9 April 2020

\begin{abstract}
Age-related macular degeneration (AMD) is a major cause of irreversible loss of vision with $80-90 \%$ of patients demonstrating dry type AMD. Dry AMD could possibly be prevented by polyphenol-rich medicinal foods by the inhibition of N-retinylidene- $\mathrm{N}$-retinylethanolamine (A2E)-induced oxidative stress and cell damage. Arctium lappa L. (AL) leaves are medicinal and have antioxidant activity. The purpose of this study was to elucidate the protective effects of the extract of AL leaves (ALE) on dry AMD models, including in vitro A2E-induced damage in ARPE-19 cells, a human retinal pigment epithelial cell line, and in vivo light-induced retinal damage in BALB/c mice. According to the total phenolic contents (TPCs), total flavonoid contents (TFCs) and antioxidant activities, ALE was rich in polyphenols and had antioxidant efficacies on 2,2-diphenyl-1-picrylhydrazyl (DPPH), 2,2'-azino-bis(3-ethylbenzothiazoline-6-sulfonic acid) (ABTS), ferric reducing antioxidant power (FRAP), and $2^{\prime}, 7^{\prime}$-dichlorofluorescin diacetate (DCFDA) assays. The effects of ALE on A2E accumulation and A2E-induced cell death were also monitored. Despite continued exposure to A2E $(10 \mu \mathrm{M})$, ALE attenuated A2E accumulation in APRE-19 cells with levels similar to lutein. A2E-induced cell death at high concentration $(25 \mu \mathrm{M})$ was also suppressed by ALE by inhibiting the apoptotic signaling pathway. Furthermore, ALE could protect the outer nuclear layer (ONL) in the retina from light-induced AMD in BALB/c mice. In conclusion, ALE could be considered a potentially valuable medicinal food for dry AMD.
\end{abstract}

Keywords: Arctium lappa L. leaves; age-related macular degeneration; A2E accumulation; A2E-induced cell death; apoptosis

\section{Introduction}

Age-related macular degeneration (AMD) is a degenerative visual disorder of the macula of the retina that affects the central vision of people aged 55 years and above in developed countries and is the leading cause of blindness. It occurs in about $8.7 \%$ people worldwide and is expected to increase 1.5 times by 2040 as average life expectancy increases [1]. AMD can be classified into dry and wet forms. Dry AMD is characterized by the formation of drusen deposits between the retinal pigment 
epithelium (RPE) and the Bruch's membrane. This is a sign of early dry AMD. Increasing symptoms gradually result in geographic atrophy (medium dry AMD), and vision decreases slowly over the years due to loss of RPE cells and photoreceptors. Dry AMD accounts for 80-90\% of AMD patients, and those with geographic atrophy progress to late AMD (wet AMD) [2]. Since patients with dry AMD do not have any early symptoms, self-awareness and prevention constitute the best management.

The main cause of dry AMD has not been identified, but some factors, such as age, smoking, hypertension, obesity, N-retinylidene-N-retinylethanolamine (A2E) accumulation, and blue light illumination, have been hypothesized to be the cause [3-6]. Among these, only A2E is an intrinsic cause. A2E is abnormally produced in the vitamin A visual cycle and is the main element of lipofuscin, one of the components of drusen [7]. Youth and adults can eliminate A2E from human RPE cells, whereas those over 50-60 years accumulate A2E in RPE due to failure of A2E removal [8]. Continuous A2E accumulation in the RPE cells triggers drusen formation in the macula where the optic nerve and optic cells gather, resulting in DNA damage in RPE cells, RPE cell death via apoptosis, and vision loss [9-11]. Therefore, inhibition of A2E accumulation and A2E-induced cell death can play an important role in preventing dry AMD and maintaining RPE function.

Arctium lappa L. (AL) is a perennial plant known as edible burdock belonging to the Asteraceae family and is distributed mainly in Asia and Europe. In Korea, AL is popularly used in food and also as traditional herbal medicine as anti-inflammatory, antipyretic, diuretic, and detoxifying agents $[12,13]$. It also has diverse biological activities, including anti-inflammatory, anti-cancer, antioxidant, neuroprotective, anti-hepatotoxic, anti-diabetic, anti-microbial, and anti-viral effects [14-17]. Most of these efficacies belong to the roots, seeds, and fruits of AL. The leaves show antimicrobial, anticancer, and antioxidant effects [18-23]. AL leaves contain a number of polyphenols, including phenolic compounds and flavonoids, that can attenuate oxidative stress. Since A2E produces oxidative stress, it is possible that the AL leaves inhibit A2E-induced damage to RPE cells, protect the retina, and prevent dry AMD.

Therefore, the purpose of this study was to investigate the protective effects of the extracts of AL leaves (ALE) on A2E accumulation and A2E-induced cell death in ARPE-19 cell, a human retinal pigment epithelial cell line, as well as to elucidate the possible mechanisms of anti-cell death. In addition, the in vivo protective effects of the extracts of AL leaves were monitored on dry AMD animal models using light source exposure to BALB/c male mice.

\section{Results}

\subsection{Extraction of AL, Total Phenolic Content (TPC), and Total Flavonoid Content (TFC) of ALE}

The extraction yield of AL was calculated on the basis of the weight of freeze-dried AL leaves (Figure 1A). Extracting from $10 \mathrm{~g}$ of AL with $100 \% \mathrm{EtOH}$ using ultrasonication yielded $1.35 \pm 0.02 \mathrm{~g}$ of ALE $(135 \pm 2 \mathrm{mg} / \mathrm{g} \mathrm{AL})$.

The TPC and TFC in ALE were analyzed at different concentrations of ALE (Figure 1B,C). The TPC of ALE was $35.79 \pm 1.4,48.95 \pm 7.94,51.2 \pm 3.34,66.49 \pm 1.6$, and $101.03 \pm 1.66 \mathrm{mg}$ gallic acid equivalent (GAE)/g ALE at 5, 10, 30, 50,100 $\mu \mathrm{g} / \mathrm{mL}$ concentration, respectively. The TFC of ALE was $1.96 \pm 0.27,19.81 \pm 0.13,22.93 \pm 0.72$, and $41.56 \pm 0.3 \mathrm{mg}$ Quercetin equivalent (QE)/g ALE at 10, 30,50 , and $100 \mu \mathrm{g} / \mathrm{mL}$ concentration, respectively. Both TPC and TFC significantly increased in a dose-dependent manner. 
A

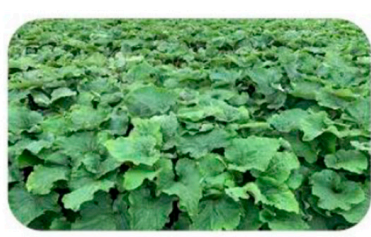

Arctium lappa L. leaves (AL)

Ultrasonic Extraction with $100 \%$ EtOH

Ethanolic Extracts (ALE)

- Extraction yield: $135 \pm 2 \mathrm{mg} / \mathrm{g} \mathbf{A L}$
B

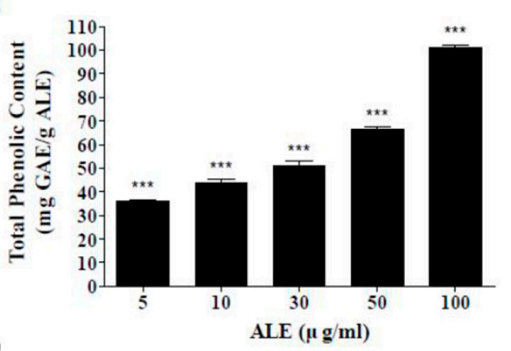

C

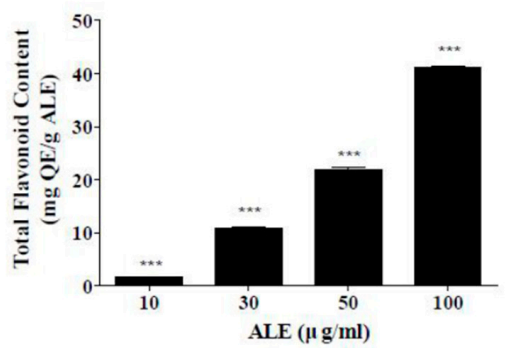

Figure 1. Extraction of AL and total polyphenol contents in extract of AL leaves (ALE). (A) Ethanolic extracts and extraction yield of ALE. (B) TPCs in ALE in a dose range from 5 to $100 \mu \mathrm{g} / \mathrm{mL}$. (C) TFCs in ALE in a dose range from 10 to $100 \mu \mathrm{g} / \mathrm{mL}$. The values represent the mean $\pm \operatorname{SD}(n \geq 3)$. ${ }^{* * *} p<0.001$ vs blank group, one-way ANOVA with Tukey's post hoc test. TPC, total phenolic content; TFC, total flavonoid content; $\mathrm{GAE}$, gallic acid equivalent; $\mathrm{QE}$, quercetin.

\subsection{Antioxidant Activities of ALE}

Antioxidant activities of ALE were monitored using 2,2-diphenyl-1-picrylhydrazyl (DPPH), ABTS, ferric reducing antioxidant power (FRAP), and $2^{\prime}, 7^{\prime}$-dichlorofluorescin diacetate assays (DCFDA) (Figure 2). DPPH radical scavenging activity of vitamin C $(30 \mu \mathrm{g} / \mathrm{mL})$ was $91.85 \pm 0.06 \%$ and that of ALE was $3.08 \pm 1.68 \%, 10.94 \pm 0.75$, and $22.83 \pm 3.41 \%$ at 30,50 , and $100 \mu \mathrm{g} / \mathrm{mL}$ concentration, respectively. DPPH radical scavenging activity of ALE significantly increased in a concentration-dependent manner.
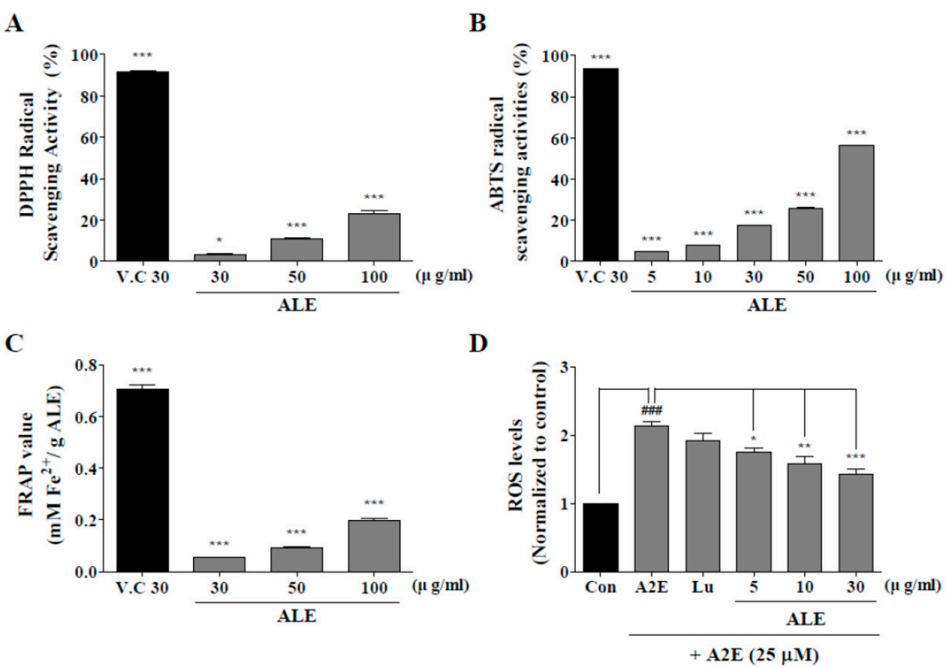

Figure 2. Antioxidant activity of ALE. 2,2-diphenyl-1-picrylhydrazyl (DPPH) radical scavenging assay (A), 2,2'-azino-bis(3-ethylbenzothiazoline-6-sulfonic acid) (ABTS) radical scavenging assay (B), and ferric reducing antioxidant power (FRAP) assay (C) were used to monitor the antioxidant activities of ALE at different doses. (D) ARPE-19 cells, a human retinal pigment epithelial cell line, were treated with ALE prior to N-retinylidene-N-retinylethanolamine (A2E) and intracellular reactive oxygen species (ROS) generation was monitored with the use of 5-(and-6)-chloromethyl-2', $7^{\prime}$-dichlorodihydrofluorescein diacetate, acetyl ester (CM- $\left.\mathrm{H}_{2} \mathrm{DCFDA}\right)$. The values represent the mean $\pm \mathrm{SD}(n \geq 3) .{ }^{*} p<0.05$, ${ }^{* * *} p<0.001$ vs blank group, one-way ANOVA with Tukey's post hoc test. 
ABTS radical scavenging activity of vitamin C was $93.48 \pm 0.25 \%$, and that of ALE was $4.53 \pm 0.21 \%$, $7.53 \pm 0.49 \%, 17.39 \pm 0.47 \%, 25.49 \pm 1.09 \%$, and $56.06 \pm 0.52 \%$ at 5, 10, 30, 50, and $100 \mu \mathrm{g} / \mathrm{mL}$ concentration, respectively. Thus, the ABTS radical scavenging activity of ALE significantly increased in a dose-dependent manner.

According to the FRAP assay, the quantified value of vitamin C was $0.71 \mathrm{mM} F e(\mathrm{II}) / \mathrm{g}$ vitamin C and that of ALE was $0.09,0.13,0.28,0.35$, and $0.64 \mathrm{mM} \mathrm{Fe}(\mathrm{II}) / \mathrm{g}$ ALE at 5, 10, 30, 50, and $100 \mu \mathrm{g} / \mathrm{mL}$ concentration, respectively. The quantification of FRAP assay with ALE also significantly increased from 30 to $100 \mu \mathrm{g} / \mathrm{mL}$.

According to DCFDA assay, intracellular reactive oxygen species (ROS) levels were successfully suppressed by ALE. A2E treatment significantly increased intracellular ROS level, whereas ALE pretreatment significantly attenuated A2E-induced intracellular ROS generation in a dose-dependent manner.

\subsection{A2E Synthesis and Optimization of A2E Concentration}

Synthesized A2E was separated by silica gel and purified to a single peak using an HPLC automated fraction collector system. Then, the chromatogram and absorbance spectrum of the purified A2E were confirmed using HPLC and spectrophotometer. The known A2E structure is shown in Figure 3A. A single peak was observed in the chromatogram of the purified A2E detected at $430 \mathrm{~nm}$ (Figure 3B). Two peaks with $\lambda \max =435$ and $345 \mathrm{~nm}$ were visible in the UV spectrum of HPLC-purified A2E (Figure 3C).
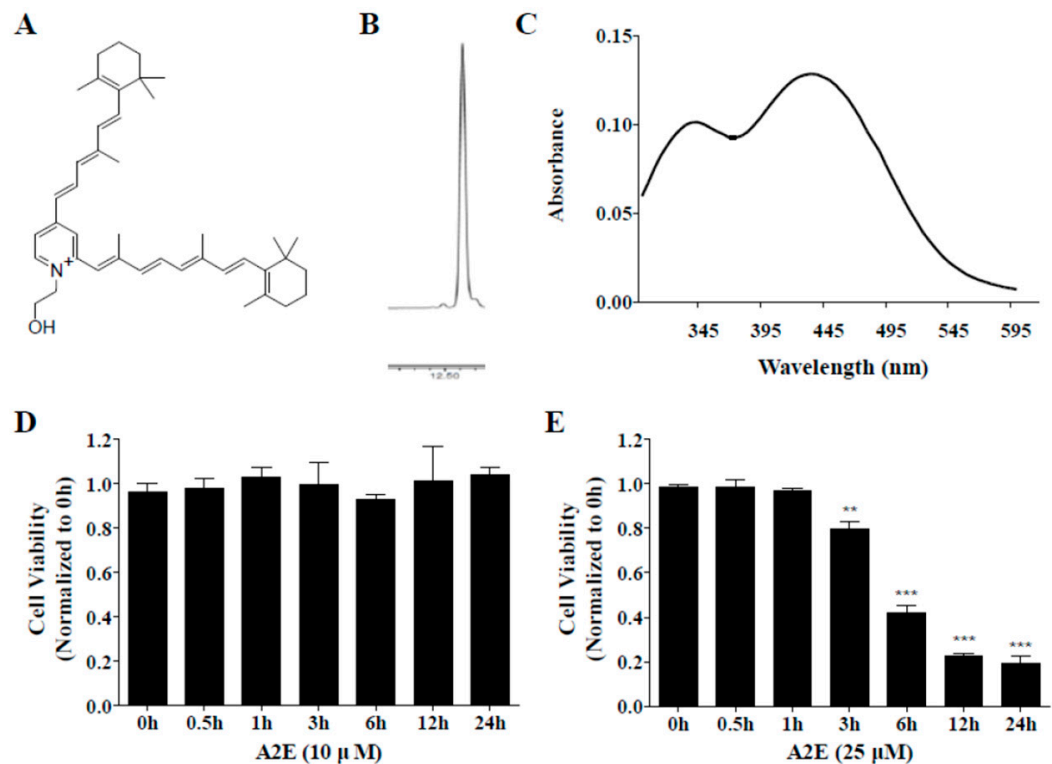

Figure 3. Characteristics of synthesized A2E. (A) Chemical structure of A2E. (B) Chromatogram of HPLC-purified A2E by HPLC. (C) UV spectra and structure of synthesized A2E. (D,E) Optimization of A2E concentration. ARPE-19 cells were treated with A2E at $10 \mu \mathrm{M}$ (D) or $25 \mu \mathrm{M}$ (E) for $24 \mathrm{~h}$, and cell viability was measured by cell counting kit (CCK)-8 kit at different time points. The values represent the mean $\pm \mathrm{SD}(n \geq 3) .{ }^{* *} p<0.01,{ }^{* *} p<0.001$ vs 0 h group, one-way ANOVA with Tukey's post hoc test.

To optimize A2E concentration for A2E-induced cell death and A2E accumulation in ARPE-19 cells, ARPE-19 cells were incubated with two concentrations of A2E (10 and $25 \mu \mathrm{M})$ for $0.5,1,3,6,12$, or $24 \mathrm{~h}$. A2E at $10 \mu \mathrm{M}$ had no effects on ARPE-19 cell viability at any time point (Figure 3D). On the other hand, cell viability of ARPE-19 cells treated with $25 \mu \mathrm{M}$ A2E showed a time-dependent decrease from 3 to $24 \mathrm{~h}\left(^{* *} p<0.01,{ }^{* * *} p<0.001\right.$ ) (Figure $3 \mathrm{E}$ ). The reduction rates were 20,60, 80, and 80\% at $3,6,12$, and $24 \mathrm{~h}$, respectively. Therefore, a lower concentration $(10 \mu \mathrm{M})$ was used to estimate the 
inhibition of A2E accumulation by ALE and a higher concentration $(25 \mu \mathrm{M})$ was chosen to investigate the suppression of A2E-induced cell death by ALE.

\subsection{Inhibition of A2E Accumulation by ALE}

The cytotoxicity of the ALE was evaluated and the effects of ALE on A2E accumulation in ARPE-19 cells were analyzed. Lutein was used as a positive control. ARPE-19 cells were treated with ALE (5, 10, $30 \mu \mathrm{g} / \mathrm{mL})$ or lutein $(5,10,30 \mu \mathrm{g} / \mathrm{mL})$ for $24 \mathrm{~h}$, and then cell viability was confirmed by using the CCK-8 kit. It was found that lutein and ALE did not affect cell viability at all concentrations (Figure 4A). Then, the effects of ALE pretreatment on A2E accumulation in ARPE-19 cells was investigated by measure intracellular A2E concentration. As shown in Figure 4B, ALE attenuated A2E accumulation in a concentration-dependent manner and significantly reduced $40 \%$ of A2E accumulation compared to the A2E-treated control at $30 \mu \mathrm{g} / \mathrm{mL}\left({ }^{* *} p<0.01\right)$. Lutein also inhibited A2E accumulation in a dose-dependent manner. Lutein at 10 and $30 \mu \mathrm{g} / \mathrm{mL}$ significantly suppressed A2E accumulation, demonstrating a $50 \%$ reduction at $30 \mu \mathrm{g} / \mathrm{mL}$ lutein $\left({ }^{*} p<0.05,{ }^{* * *} p<0.001\right)$.

A

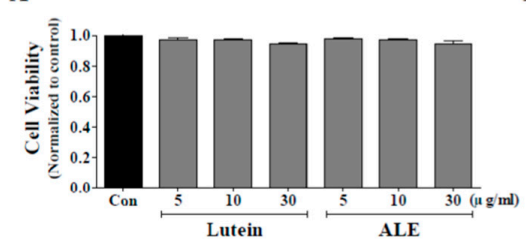

C

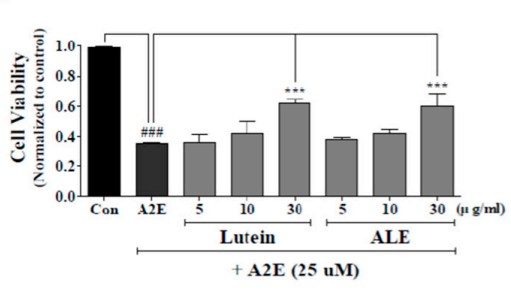

B

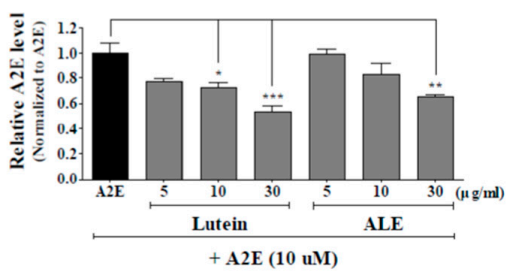

D

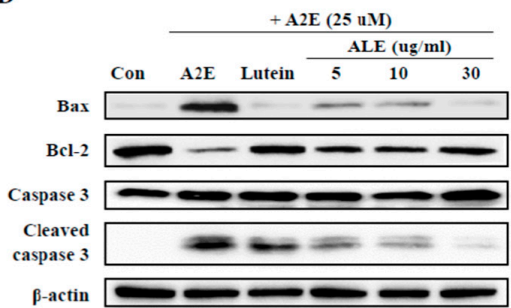

Figure 4. Protective effects of ALE on A2E accumulation and A2E-induced cell death in ARPE-19 cells. (A) Cell viability of ARPE-19 cells treated only with lutein or ALE. ARPE-19 cells were incubated with lutein or $\operatorname{ALE}(5,10,30 \mu \mathrm{g} / \mathrm{mL})$ for $24 \mathrm{~h}$ and the cell viability was measured using the CCK-8 kit. (B) Inhibition of intracellular A2E accumulation by ALE pretreatment. ARPE-19 cells were treated with $\operatorname{ALE}(5,10$, and $30 \mu \mathrm{g} / \mathrm{mL})$ on days 2,5 , and 8 , and with A2E $(10 \mu \mathrm{M})$ on days 3,6 , and 9. On the last day (day 10), A2E in ARPE-19 cells was extracted, analyzed by HPLC, quantified using an external A2E standard curve, and normalized to protein level. The values represent the mean \pm SD $(n \geq 3) .{ }^{*} p<0.05,{ }^{* *} p<0.01,{ }^{* *} p<0.001$ vs A2E group, one-way ANOVA with Tukey's post hoc test. (C) Inhibition of A2E-induced cell death by ALE pretreatment. ARPE-19 cells were incubated with lutein or $\operatorname{ALE}(5,10$, and $30 \mu \mathrm{g} / \mathrm{mL})$ for $24 \mathrm{~h}$, prior to A2E treatment $(25 \mu \mathrm{M})$ for $24 \mathrm{~h}$. Then, cell viability was measured by 3-(4,5-dimethylthiazol-2-yl)-2,5-diphenyltetrazolium bromide (MTT) assay. The values represent the mean $\pm \mathrm{SD}(n \geq 3)$. ${ }^{\# \#} p<0.001$ vs C (control) group; ${ }^{* * *} p<0.001$ vs A2E group, one-way ANOVA with Tukey's post hoc test. (D) Protein expression of apoptosis-associated factors in A2E-laden APRE-19 cells.

\subsection{Protective Effect of ALE on A2E-Induced ARPE-19 Cell Death by Inhibiting the Apoptotic Signaling Pathway}

ARPE-19 cells were treated with $25 \mu \mathrm{M}$ A2E for $24 \mathrm{~h}$ with or without pretreatment with ALE (5, $10,30 \mu \mathrm{g} / \mathrm{mL}$ ) for $24 \mathrm{~h}$, and the protective effect of ALE against A2E-induced cell death was monitored using 3-(4,5-dimethylthiazol-2-yl)-2,5-diphenyltetrazolium bromide (MTT) assay (Figure 4C). Cell viability of ARPE-19 cells was significantly reduced by more than $60 \%$ by A2E treatment $\left({ }^{* *} p<0.001\right)$. ALE showed a slight increase in cell viability at 5 and $10 \mu \mathrm{g} / \mathrm{mL}$ but a significant increase in cell 
viability (around $20 \%$ at $30 \mu \mathrm{g} / \mathrm{mL}$ ) compared to A2E-treated control $\left({ }^{* * *} p<0.001\right)$. Lutein increased cell viability in a concentration-dependent manner but significantly increased to about $20 \%$ at $30 \mu \mathrm{g} / \mathrm{mL}$. The protective effect of ALE against A2E-induced cell death was similar to that of lutein.

Apoptosis is one of the ARPE-19 cell death induced by A2E, so changes in apoptosis-associated protein expression were monitored using Western blot analysis (Figure 4D). A2E treatment $(25 \mu \mathrm{M})$ to ARPE-19 cells caused apoptosis, so protein levels of Bax and cleaved caspase 3 were upregulated, and that of $\mathrm{Bcl}$ were downregulated, compared to the control. However, ALE treatment to ARPE-19 cell prior to A2E suppressed apoptosis. The protein levels of Bax and cleaved caspase 3 in ALE-treated cells were lower than in ALE-untreated cells, and that of Bcl-2 in ALE-treated cells was higher than in ALE-untreated cells in a dose-dependent manner. The positive control, lutein, also demonstrated the same effects as ALE.

\subsection{Inhibitory Effect of ALE on Retinal Damage Caused by White Light}

To investigate the effect of ALE on the histological damage of the retina by white light, hematoxylin and eosin (H\&E) staining was done (Figure 5A). Light + vehicle exposure group demonstrated histological disturbance of outer segments and inner segments (OS/IS), outer nuclear layer (ONL), inner nuclear layer (INL), and ganglion cell layer (GCL) compared to the control group. The lutein-treated group, a positive control group, moderated the histological disturbances of OS/IS, ONL, INL, and GCL layers compared to the vehicle group despite exposure to light. Similarly, the ALE treatment group mitigates histological disturbances in OS/IS, ONL, INL, and GCL layers depending on the concentration. Figure 5B, which depicts quantified values of these histological disturbances, shows that ALE and lutein significantly inhibited light-induced retinal damage in a dose-dependent manner. According to this result, ALE could protect retinal damage from white light.

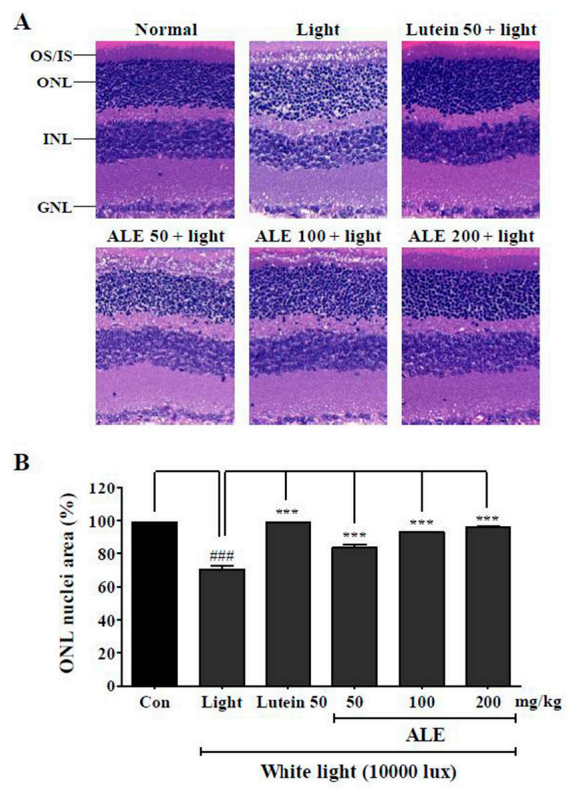

Figure 5. Inhibitory effect of ALE on light-induced retinal damage. (A) Representative hematoxylin and eosin (H\&E) stained images in light-induced age-related macular degeneration (AMD) model. BALB/c mice $(n=6)$ were treated with vehicle, lutein $(50 \mathrm{mg} / \mathrm{kg})$, or ALE $(50,100$, and $200 \mathrm{mg} / \mathrm{kg})$ for 4 weeks and exposed to white light at 10,000 lux in light cages for $6 \mathrm{~h}$. After exposure, mice were given inhaled anesthesia with isoflurane immediately and were euthanized to remove the eyes. (B) Stained region in ONL layer was calculated using metamorph and expressed in ONL nuclei area (\%). The values represent the mean $\pm \mathrm{SD}(n=3)$. ${ }^{\# \# \#: ~} p<0.001$ vs control group; ${ }^{* * *} p<0.001$ vs light exposure group, one-way ANOVA with Tukey's post hoc test. OS, outer segments; IS, inner segments; ONL, outer nuclear layer; INL, inner nuclear layer; GCL, ganglion cell layer. 


\section{Discussion}

This study showed that: (1) ALE contains a large amount of polyphenols, including phenolic compounds and flavonoids, and shows antioxidant effects; (2) A2E accumulation is significantly suppressed by ALE in a concentration-dependent manner; (3) ALE protects ARPE-19 cells against A2E in a concentration-dependent manner by inhibiting the apoptosis signaling pathway; and (4) ALE successfully attenuates retinal damage using a light-induced animal model of dry AMD. These findings indicated that ALE could be functional food/ medicines for the prevention of AMD development and progression.

AMD is a disease that causes blindness due to the damage and death of RPE cells and photoreceptor cells [24]. The molecular hallmark of AMD, especially dry AMD, is the presence and accumulation of drusen within RPE cells or in the interface between RPE cells and Bruch's membrane [25]. Drusen contains diverse components, including lipofuscin, complement components, apolipoprotein E, amyloid P component, and complement factor $\mathrm{H}$ [25-29]. Most drusen is lipofuscin, and more than $90 \%$ of the lipofuscin was generated from the visual retinoid cycle and was resistant to degradation by lysosomes and proteasomes from RPE cells with aging. A major component of lipofuscin from the RPE cells is a fluorophore A2E [30]. A2E is a cytotoxic lipofuscin bis-retinoid, formed from the reaction between all-trans-retinal and ethanolamine in the photoreceptor cells, and is accumulated in the RPE cells [31]. A2E-laden cells increase chronic oxidative stress and excessive A2E leads to cell death $[32,33]$. A2E can be amassed in human RPE cells in vivo up to $60-130 \mathrm{ng} / 10^{5}$ cells, and does not cause significant damage to DNA up to $20 \mu \mathrm{M}[34,35]$. In addition, $10 \mu \mathrm{M}$ A2E has no effect on the cell viability of ARPE-19 cells for $48 \mathrm{~h}$, whereas 25 and $50 \mu \mathrm{M}$ A2E trigger cell death in a time dependent manner [36,37]. We also described the same results as the effect of A2E (10 and $25 \mu \mathrm{M})$ on ARPE-19 cell viability that can reflect clinical phenomena for lipofuscin accumulation and damage over a lifespan.

Lipofuscin, such as A2E, can be accumulated in lysosomes and cytosol. Lysosomal lipofuscin triggers not only protein oxidation, aggregation, and lipofuscin production but also the induction of oxidative stress by destructive contributions of autophagy and lysosomal degradation. Cytosolic lipofuscin also generates ROS. Therefore, cytosolic protein degradation suffers, and cell viability decreases. With age, lipofuscin aggregates in RPE cells, producing more oxidative stress. A2E produces free radicals in organized media and produces radicals, such as superoxide and peroxyl $[38,39]$. Therefore, suppressing oxidative stress will be valuable in preventing AMD.

Plant-based foods contain a large amount of polyphenols with antioxidant properties [40]. ALE also consist of phenolic compounds and flavonoids and showed antioxidant efficacy. According to antioxidant assays, ALE significantly cause DPPH radical, ABTS radical and ferrous ion $\left(\mathrm{Fe}^{2+}\right)$ scavenging activity and significantly decrease A2E-induced intracellular ROS generation. Phenolic compounds and flavonoids prevent oxidative stress-associated retinal disease. AL leaves also contain polyphenols, such as chlorogenic acid, 1, 5-dicaffeoylquinic acid, caffeic acid, arctiin, rutin, luteolin, and quercetin $[19,20]$. Most of these showed antioxidant effects according to DPPH, ABTS, and FRAP assays. Furthermore, some compounds, such as chlorogenic acid and quercetin, can defend RPE cells from light and oxidative damage using cell-based assays, which work by inhibiting apoptotic pathways [41,42]. Natural antioxidants, such as zeaxanthin, lutein, bilberry, and polyphenol compounds, have protective effects on A2E-induced APRE-19 cell death [43,44]. In addition, the extracts of polyphenol-rich Vaccinium uliginosum L. or Prunella vulgaris var. L. inhibit blue light-induced apoptosis in cells containing A2E in vitro and in vivo [45-47]. Therefore, ALE could affect APRE-19 cell viability against A2E.

ALE protected ARPE-19 cells against A2E by two means: regulation of intracellular A2E accumulation, and modulation of A2E-laden cell death by regulating the apoptotic signaling pathway. Despite the continuous A2E exposure $(10 \mu \mathrm{M})$, ALE inhibited the increase of intracellular A2E concentration in a dose-dependent manner with levels similar to lutein, compared with A2E-treated control. In addition, ALE successfully suppressed ARPE-19 cell death against A2E, similar to lutein. The mechanism of lipofuscin accumulation in RPE cells is not exactly known, but is believed to be proteostasis. Aging attenuates cellular proteolysis. Consequently, unremoved misfolded proteins 
form complexes with perinuclear/centrosomal-proximal proteins, which produce aggresomes [48-52]. Lipofuscin is one of these aggresomes and is located within lysosomes via macroautophagy, and in cytosol [53]. Accumulated lipofuscin causes a vicious cycle. The large amount of lipofuscin suppresses proteasomes, impedes the breakdown of oxidized proteins, increases ROS generation, and then induces additional lipofuscin formation [54-56]. Finally, lipofuscin causes cytotoxicity in RPE cells. Lipofuscin-laden RPE cells cause dysfunction and undergo apoptosis via the intrinsic pathway [57]. During intrinsic apoptosis, anti-apoptotic proteins, such as Bcl-2, are deactivated and pro-apoptotic protein, such as Bax, are activated. This promotes the release of cytochrome $\mathrm{C}$ and formation of cleaved caspase 3. This study showed that ALE suppressed A2E-induced apoptosis by the upregulation of Bcl-2 and downregulation of Bax and cleaved caspase 3. Therefore, ALE could potentially prevent and inhibit A2E-mediated dry AMD by the inhibition of oxidative stress, A2E accumulation, and apoptosis.

The protective effect of ALE shown in vitro was correlated with an in vivo animal model. BALB/C mice were exposed to high power white light (10,000 lux). The light source did not reduce the thickness of the ONL layer, as in previous research, because we sacrificed the mice immediately after light exposure. However, histological disturbances in the OS/IS, ONL, INL, and GNL layers were observed when compared with the control. This phenomenon hass also appeared in other research, like that of Shibagaki et al. (2015), who showed the destruction of IS/OS and irregular ONL [58]. The density between the nuclei in the retina in ALE- or lutein-treated group was higher than in the light-treated group. ALE protected the retina in a dose-dependent manner, and the efficacy of $200 \mathrm{mg} / \mathrm{kg}$ ALE was similar to that of $50 \mathrm{mg} / \mathrm{kg}$ lutein. For the AMD in vivo study, a single animal model could not be used as it would not represent all the signs of AMD [59]. However, a common phenomenon exists in all animal models. The common features of AMD are generation of oxidative stress, loss of ONL thickness, and a histological disturbance in the whole layer [60]. Rodent retina is composed of OS/IS, ONL, INL, and GNL layers. After AMD induction, intracellular organelles, such as DNA, are damaged by the generated ROS. The number of nuclei in the retinal layers is reduced and most retinal layers, especially the ONL layer, become thin. Monitoring these changes may contribute to understanding the effects of medicinal foods or medicines. Many research studies have shown that light sources (white or blue) cause apoptosis in the photoreceptors of animal models [45-47,61]. This light-inducing AMD animal model was used for the discovery of AMD-protected medicinal plants or foods, such as the extracts of Prunella vulgaris var. L., Curcuma longa L., and Vaccinium uliginosum L. These research studies observed H\&E stained retinal images and analyzed changes in the thickness of the whole retinal layer or ONL layer. The extracts effectively protect the retinal layer or ONL layer against blue light. Lutein, a well-known medicine for AMD treatment, also inhibits light-induced damage in retina similarly.

ALE had antioxidant efficacy and appeared to protect ARPE-19 cells by inhibiting A2E accumulation and apoptosis against A2E. ALE also suppressed light-induced retinal damage in $\mathrm{BALB} / \mathrm{c}$ mice. Considering human equivalent dose (HED) and extraction yield of ALE, taking the extract is more effective for preventing dry AMD than taking raw ingredients. Equivalent doses of ALE at 50, 100, and $200 \mathrm{mg} / \mathrm{kg}$ BW in mice are 4.05, 8.1, and $16.2 \mathrm{mg} / \mathrm{kg} \mathrm{BW}$ in human, and the serving size for $16.2 \mathrm{mg}$ ALE/kg BW is $120 \mathrm{mg} \mathrm{AL} / \mathrm{kg}$ BW due to extraction yield ( $135 \mathrm{mg} / \mathrm{g} \mathrm{AL}$ ). Thus, ALE could be a potentially preventive medicinal food for dry AMD.

\section{Materials and Methods}

\subsection{Reagents}

AL leaves were purchased from Jirisan Starmaru (Sancheong, Korea). Lutein powder (40\%) was received as a present from the Novarex Co., Ltd. (Seoul, Korea). Sodium hydroxide (NaOH), sodium nitrite $\left(\mathrm{NaNO}_{2}\right)$, aluminium (III) chloride $\left(\mathrm{AlCl}_{3}\right)$, and sodium carbonate $\left(\mathrm{Na}_{2} \mathrm{CO}_{3}\right)$ were acquired from Junsei Chemicals (Tokyo, Japan). All-trans-retinal, triton X-100, ethanolamine, acetic acid, ascorbic acid, gallic acid, 2,2-diphenyl-1-picrylhydrazyl (DPPH), ABTS tablets, ABTS buffer, 2,4,6-tripyridyl-S-triazine (TPTZ), quercetin, potassium persulfate, iron(III) chloride ( $\left.\mathrm{FeCl}_{3}\right)$, dimethyl 
sulfoxide (DMSO), chloroform, and Folin-Ciocalteau reagent were obtained from Sigma-Aldrich (St. Louis, MO, USA). Ethanol (EtOH) was purchased from Merck (Darmstadt, Germany). Methanol $(\mathrm{MeOH})$, acetonitrile, and water were procured from JT BAKER Chemical Co., (Phillipsburg, NJ, USA). Trifluoroacetic acid (TFA) and sodium acetate were purchased from Thermo Fisher Scientific (Waltham, MA, USA). 1N Hydrochloric acid was obtained from DAESUNG Co, Ltd. (Siheng, Korea). Polyclonal anti-cleaved-caspase-3, anti-caspase-3, anti-Bcl-2, and anti-Bax antibodies were purchased from Cell Signaling Technology Inc. (Danvers, MA, USA). A stock solution of lutein was prepared at a concentration of $10 \mathrm{mM}$ in DMSO. DMSO in the culture media was less than $0.1 \%$.

\subsection{Ethanolic Extraction of AL Leaves}

Fresh AL leaves were washed with flowing water, cut to a suitable size, and lyophilized. Freeze-dried AL $(10 \mathrm{~g})$ was added to ethanol $(500 \mathrm{~mL})$, and the mixture was extracted by ultrasonication using an ultrasonic processor (VCX 750; Sonics \& Materials, Newtown, CT, USA) for $2 \mathrm{~h}$. The treatment conditions were as follows: $750 \mathrm{~W}$ power output, $20 \mathrm{kHz}$ frequency, $80 \%$ amplitude, and $03 \mathrm{~s} / 03 \mathrm{~s}$ pulses. The temperature was maintained at $4{ }^{\circ} \mathrm{C}$ during ultrasonication using a low-temperature bath (NCB-2200; EYELA Co., Tokyo, Japan). ALE was concentrated using a rotary evaporator (EYELA Co., Tokyo, Japan), freeze-dried, and stored at $-80^{\circ} \mathrm{C}$. For cell treatment, ALE was dissolved in DMSO to yield $100 \mathrm{mg} / \mathrm{mL}$ stocks and ALE stock solution $(100 \mathrm{mg} / \mathrm{mL})$ was diluted at each concentration in a culture medium. The final concentration of DMSO in media was less than $0.1 \%$.

\subsection{Synthesis of $A 2 E$}

A2E was synthesized from all-trans-retinal and ethanolamine [35]. Mixtures of all-trans-retinal, ethanolamine, and acetic acid in ethanol were stirred in the dark, at room temperature, for $72 \mathrm{~h}$. The mixture was purified by silica gel column chromatography. The mixture was loaded in a silica gel column that was prewashed with a mixed solvent (methanol: dichloromethane $=5: 95$ ). Then, A2E was eluted with a mixed solvent (methanol: dichloromethane $=8: 92$ ) containing $0.02 \%$ TFA. After separation, $\mathrm{A} 2 \mathrm{E}$ was concentrated under nitrogen gas in a concentrator and purified to a single peak using Ultimate 3000 HPLC system (Dionex Corporation, Sunnyvale, CA, USA) with an automated fraction collector system (AFC-3000 UltiMate Fraction Collector; Thermo-Fisher Scientific, Waltham, MA, USA). The purified A2E was confirmed by a chromatogram and absorbance spectrum using HPLC and spectrophotometer, respectively. A2E stock solution was $10 \mathrm{mM}$ in DMSO and was stored at $-20^{\circ} \mathrm{C}$ in the dark. In each experiment, A2E stock solution was diluted in a culture media at concentration of 10 and $25 \mu \mathrm{M}$.

\subsection{Cell Culture}

ARPE-19, a human RPE cell from American Type Culture Collection (ATCC; Manassas, VA, USA), was grown in Dulbecco's modified Eagle's medium Nutrient Mixture F-12 (DMEM/F12, Gibco, Gaithersburg, MD, USA) supplemented with 10\% heat-inactivated fetal bovine serum (FBS, Gibco, Gaithersburg, MD, USA) and 1\% penicillin/streptomycin (Gibco, Gaithersburg, MD, USA) at $37^{\circ} \mathrm{C}$ in $5 \% \mathrm{CO}_{2}$. When ARPE- 19 cells were grown to $70-80 \%$ confluence on culture dishes, cells were seeded on 96-well or 24-well microplates $\left(2 \times 10^{4}\right.$ cells/well or $1 \times 10^{5}$ cells/well, respectively) and used in all experiments.

\subsection{Determination of Total Phenolic Contents (TPCs)}

TPCs were measured by modifying the Folin-Ciocalteu method [62]. The extract (125 $\mu \mathrm{L})$ was diluted at each concentration with $\mathrm{MeOH}$ and mixed with $1 \mathrm{~N}$ Folin-Ciocalteau reagent $(375 \mu \mathrm{L})$ in a $1.5 \mathrm{~mL}$ tube, at room temperature, for $5 \mathrm{~min}$. After $5 \mathrm{~min}, 700 \mathrm{mM}$ sodium carbonate solution $(500 \mu \mathrm{L})$ was added thereto, mixed, and allowed to react for $1 \mathrm{~h}$. Then, the absorbance of the supernatant was measured at $765 \mathrm{~nm}$ using a spectrophotometer (SpectraMax M2e, Molecular Devices, Sunnyvale, CA, USA). TPCs were calculated from a calibration curve with gallic acid and depicted as milligrams of 
gallic acid equivalent (GAE) per gram of dry weight of ALE (mg GAE/g ALE). The calibration curve for GAE was obtained using $0.00625,0.0125,0.025,0.05$, and $0.1 \mathrm{mg} / \mathrm{mL}$ gallic acid in $100 \% \mathrm{MeOH}$.

\subsection{Determination of Total Flavonoid Contents (TFCs)}

TFC was determined according to the aluminum chloride colorimetric method [63]. The extracts in $\mathrm{MeOH}$ were sequentially reacted with $5 \% \mathrm{NaNO}_{2}$ for $6 \mathrm{~min}, 10 \% \mathrm{AlCl}_{3}$ for $5 \mathrm{~min}$, and $1 \mathrm{M} \mathrm{NaOH}$, for $15 \mathrm{~min}$, at room temperature. The absorbance of the mixture was measured at $492 \mathrm{~nm}$ with a spectrophotometer. TFCs were calculated from a calibration curve with quercetin and were expressed in terms of milligrams of Quercetin equivalent (QE) per gram of dry weight of ALE (mg QE/g ALE). The standard curve for QE was obtained using $0.00625,0.0125,0.025,0.05$, and $0.1 \mathrm{mg} / \mathrm{mL}$ of quercetin in $100 \% \mathrm{MeOH}$.

\subsection{Determination of Antioxidant Capacity}

\subsubsection{DPPH Radical Scavenging Assay}

The extracts in $\mathrm{MeOH}$ was mixed with $0.4 \mathrm{mM}$ DPPH solution and incubated in the dark, at room temperature, for $30 \mathrm{~min}$. The absorbance of the reaction solution was read at $517 \mathrm{~nm}$. Ascorbic acid (30 $\mu \mathrm{g} / \mathrm{mL}$ ) was used as a positive control. DPPH radical scavenging activity was expressed as percentage according to the following equation.

$$
\text { DPPH radical scavenging activity }(\%)=\left(\frac{\text { Abs Control }- \text { Abs Sample }}{\text { Abs Control }}\right) * 100 \text {. }
$$

\subsubsection{ABTS Radical Scavenging Assay}

A mixture of $2.45 \mathrm{mM}$ potassium persulfate solution and $7 \mathrm{mM}$ ABTS solution in a 1:1 ratio

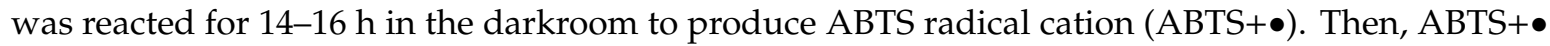
solution with $0.70 \pm 0.02$ absorbance at $734 \mathrm{~nm}$ was obtained by dilution in $\mathrm{MeOH}$. The extracts in $\mathrm{MeOH}$ and $\mathrm{ABTS}+\bullet$ solution in a 1:1 ratio were reacted in the dark, at room temperature, for $10 \mathrm{~min}$. The absorbance of the reaction solution was measured at $734 \mathrm{~nm}$. Ascorbic acid $(30 \mu \mathrm{g} / \mathrm{mL})$ was used as a positive control. ABTS radical scavenging activity was expressed as percentage according to the following equation:

$$
\text { ABTS radical scavenging activity }(\%)=\left(\frac{\text { Abs Control }- \text { Abs Sample }}{\text { Abs Control }}\right) * 100 \text {. }
$$

\subsubsection{Ferric Reducing Antioxidant Power (FRAP) Assay}

Acetate buffer (0.3 M, pH 3.6) in D.W, TPTZ solution $(10 \mathrm{mM})$ in $40 \mathrm{mM} \mathrm{HCl}$, and $\mathrm{FeCl}_{3}$ solution $(20 \mathrm{mM})$ in D.W were prepared. Then, acetate buffer, TPTZ solution, and $\mathrm{FeCl}_{3}$ solution were mixed in a ratio of 10:1:1 and allowed to react at $37^{\circ} \mathrm{C}$ for $10 \mathrm{~min}$ to make the FRAP reagent. The extracts and FRAP reagent were mixed in a ratio of $1: 10$ at $37^{\circ} \mathrm{C}$ for $10 \mathrm{~min}$, and absorbance was measured at $593 \mathrm{~nm}$. The FRAP value was calculated using the calibration curve with Trolox and expressed as $\mathrm{mM}$ of ferrous ion $\left(\mathrm{Fe}^{2+}\right)$ per gram of ALE. Ascorbic acid $(30 \mu \mathrm{g} / \mathrm{mL})$ was used as a positive control.

\subsubsection{2', $7^{\prime}$-Dichlorofluorescin Diacetate (DCFDA) Assay}

Generated intracellular ROS was detected using DCFDA assay. ARPE-19 cells in 96-well plates were treated with the extracts at 5,10 , and $30 \mu \mathrm{g} / \mathrm{mL}$ for $1 \mathrm{~h}$, washed with phosphate-buffered saline (PBS), and then, treated with $25 \mu \mathrm{M}$ A2E for $1 \mathrm{~h}$. As a control, ARPE-19 cells were pre-incubated with $0.1 \%$ DMSO for $1 \mathrm{~h}$ and then with or without A2E $(25 \mu \mathrm{M})$ for $1 \mathrm{~h}$. Lutein $(30 \mu \mathrm{g} / \mathrm{mL})$ was used as a positive control. During the last $30 \mathrm{~min}$, cells were stained with 5-(and-6)-chloromethyl-2', $7^{\prime}$-dichlorodihydrofluorescein diacetate, acetyl ester (CM- $\mathrm{H}_{2}$ DCFDA, $10 \mu \mathrm{M}$; Thermo Fisher Scientific, Waltham, MA, USA) in an 
incubator. Then, the cells were washed with PBS and the Relative Fluorescent Unit (RFU) in the cells was monitored using a spectrophotometer at excitation and emission wavelengths of 488 and $525 \mathrm{~nm}$, respectively. All experiments were carried out in the dark to diminish photo-oxidation and photo-reduction.

\subsection{Cell Viability Assay}

To optimize A2E concentration, the cell viability was determined using cell counting kit-8 (CCK-8, Enzo Life Science, Farmingdale, NY, USA). ARPE-19 cells in 96-well microplate were treated with $10 \mu \mathrm{M}$ and $25 \mu \mathrm{M}$ of A2E solution. At each time point $(0,0.5,1,3,6,12$, and $24 \mathrm{~h}), \mathrm{A} 2 \mathrm{E}-$ containing culture medium was replaced to $100 \mu \mathrm{L}$ of culture media containing $10 \mu \mathrm{L}$ of CCK-8 solution in each well and further incubation was carried out for $2 \mathrm{~h}$ at $37^{\circ} \mathrm{C}$. The absorbance was measured at $450 \mathrm{~nm}$ using a spectrophotometer and normalized as follows:

$$
\text { Cell viability }=\text { absorbance at each time point/ absorbance at } 0 \mathrm{~h} \text {. }
$$

Cytotoxicity of ALE was estimated using CCK-8. ARPE-19 cells in 96-well were treated with $\operatorname{ALE}(5,10$, and $30 \mu \mathrm{g} / \mathrm{mL})$ or lutein $(5,10$, and $30 \mu \mathrm{g} / \mathrm{mL})$ for $24 \mathrm{~h}$, washed with PBS, and incubated with CCK-8 reagent for $2 \mathrm{~h}$. The absorbance was measured at $450 \mathrm{~nm}$ using a spectrophotometer. The absorbance of each experimental group was normalized to absorbance of $0.1 \%$ DMSO-treated control group.

The MTT cell viability assay was used to monitor the effect of A2E on ALE-pretreated ARPE-19 cells. ARPE-19 cells pretreated with ALE $(5,10$, and $30 \mu \mathrm{g} / \mathrm{mL})$ or lutein $(5,10$, and $30 \mu \mathrm{g} / \mathrm{mL})$ for $24 \mathrm{~h}$ were washed with PBS and incubated with A2E $(25 \mu \mathrm{M})$ for $24 \mathrm{~h}$. After $24 \mathrm{~h}$, MTT assay was carried out and the absorbance was measured at $570 \mathrm{~nm}$ using a spectrophotometer. The absorbance was normalized as follows:

Cell viability $=$ absorbance of each experimental group/absorbance of control group.

\subsection{Intracellular A2E Accumulation}

Accumulated intracellular A2E is measured by the method depicted in Figure 6A. ARPE-19 cells $\left(1 \times 10^{5}\right.$ cells/well $)$ were seeded in 24 -well plates on 1 st day. Thereafter, ARPE-19 cells were treated with ALE or lutein at 5, 10, and $30 \mu \mathrm{g} / \mathrm{mL}$ on 2nd, 5th, and 8th days and with A2E $(10 \mu \mathrm{M})$ on the 3rd, 6th, and 9th day. Washing with PBS was performed between sample and A2E treatment. On the last day (10th day), ARPE-19 cells were washed with PBS, scraped and harvested in the presence of $0.5 \%$ triton X-100. Collected cells were sonicated for $1 \mathrm{~min}$ to destroy the layers. Some of cell lysates were used to measure protein levels using BCA assay, and most were used to quantify accumulated A2E as follows; Cell lysate was extracted three times with chloroform added each time. Collected fraction containing A2E in chloroform was filtered using polytetrafluoroethylene (PTFE) filter, evaporated under nitrogen gas, and dissolved in ethanol for HPLC analysis. HPLC system consists of Dionex Ultimate-3000 (Thermo Scientific, Sunnyvale, CA, USA) with a quaternary pump, an autosampler, a UV-Vis diode array detector (DAD3000; Thermo Scientific, Sunnyvale, CA, USA), and a reverse-phase C18 column $(4.6 \times 250 \mathrm{~mm} ; 5 \mu \mathrm{m}$ particle size; Agilent Technologies, Santa Clara, CA, USA). The detection wavelength for A2E was set at 340 and $430 \mathrm{~nm}$. The mobile phase comprised of water with $0.1 \%$ TFA (solvent A) and acetonitrile with $0.1 \%$ TFA (solvent B). A2E was eluted as follows: $85 \%$ solvent $B$ in the beginning, increased to $96 \%$ in $10 \mathrm{~min}$, maintained for $5 \mathrm{~min}$, increased to $100 \%$ solvent B in $17 \mathrm{~min}$, and maintained until $25 \mathrm{~min}$. The flow rate was set to $1 \mathrm{~mL} / \mathrm{min}$. The sample injection volume was $10 \mu \mathrm{L}$, and all standards and samples were filtered through a $0.2 \mu \mathrm{m}$ PTFE 
filter before injection. A2E was quantified using external standard and divided by protein level (A2E concentration/protein value). Then, quantified $\mathrm{A} 2 \mathrm{E}$ was normalized as follows:

$$
\text { Relative A2E level }=\frac{\mathrm{A} 2 \mathrm{E} \text { amount in each experimental group }}{\mathrm{A} 2 \mathrm{E} \text { amount in } \mathrm{A} 2 \mathrm{E}-\text { treated control group }} .
$$

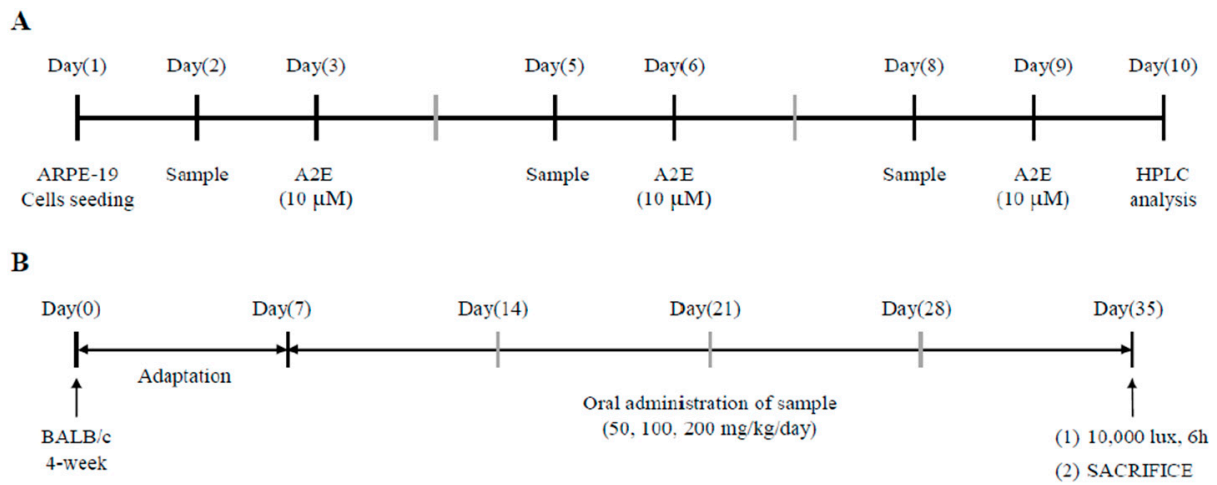

Figure 6. Scheme of treatment schedule. (A) Schedule for the inhibitory effect of ALE on A2E accumulation in ARPE-19 cells. (B) Schedule for rodent study.

\subsection{Western Blotting}

ARPE-19 cells were treated with the extract at 5, 10, and $30 \mu \mathrm{g} / \mathrm{mL}$ for $24 \mathrm{~h}$ and with A2E $(25 \mu \mathrm{M})$ for $24 \mathrm{~h}$. Then, the cells were harvested and lysed with lysis RIPA buffer (150 mM NaCl, $1 \%$ Triton X-100, 1\% sodium deoxycholate, 0.1\% SDS, 50 mM Tris-HCl (pH 7.5), 2 mM EDTA (pH 8.0)) containing protease inhibitor cocktail and phosphatase inhibitor cocktail. The protein obtained was electrophoresed with $12 \%$ sodium dodecyl sulfate-polyacrylamide gel electrophoresis (SDS-PAGE) and transferred to a polyvinylidene fluoride (PVDF) membrane, which was blocked with $5 \%$ bovine serum albumin (BSA) for $2 \mathrm{~h}$, incubated overnight with the primary antibodies (Bax, Bcl-2, caspase 3, and cleaved caspase 3 ) at $4{ }^{\circ} \mathrm{C}$, and treated with secondary antibody for $2 \mathrm{~h}$. Protein expressions of Bax, Bcl-2, caspase 3, and cleaved caspase 3 were detected using Western blotting detection enhanced chemiluminescence (ECL) reagent. Expression levels were visualized using a Vilber Fusion Solo $S$ chemiluminescence acquisition system (Vilber Lourmat, France).

\subsection{Animal Study}

Animal experiments were used in accordance with the guidelines of the Animal Control and Use Committee (IACUC) of the Korea Food Research Institute (KFRI-M-19049). BALB/c male mice (4 week-old) were purchased from Orient Bio, Inc. (Seongnam, Korea). Mice were housed in standard cage and maintained at a temperature of $23 \pm 2{ }^{\circ} \mathrm{C}, 50 \pm 10 \%$ humidity, and periodic illumination (130-350 lux, $12 \mathrm{~h}$ light-dark cycle) with free access to standard laboratory chow and tap water ad libitum. The scheme of the animal study is shown in Figure 6B. After adaption for 1 week, mice were divided into six different groups and group-housed ( $n=6$ for each group, three mice per cage): control, only light exposure, light $+50 \mathrm{mg} / \mathrm{kg}$ body weight (BW)/day of lutein, light $+50 \mathrm{mg} / \mathrm{kg} \mathrm{BW} /$ day of ALE, light $+100 \mathrm{mg} / \mathrm{kg}$ BW/day of ALE, and light $+200 \mathrm{mg} / \mathrm{kg} \mathrm{BW} /$ day of ALE. ALE dissolved in PBS was orally administered for 4 weeks (5 days/week). The control and only light exposure groups received the vehicle (PBS) for 4 weeks by oral gavage (5 days/week). After 4 weeks, the mice, except those in the control group, were exposed to light with a white lamp (10,000 lux) for $6 \mathrm{~h}$ in a light cage with stainless steel walls and bottom. The cage contained a ventilator, and the mice were subjected to dark adaptation for $12 \mathrm{~h}$ before light exposure. The control group was maintained in the light box without light. 
After $6 \mathrm{~h}$ of light exposure, the mice were immediately given inhaled anesthesia with isoflurane and were euthanized to remove the eyes. The extracted eye was fixed in $4 \%$ paraformaldehyde (PFA) and then embedded in paraffin wax. The paraffin-embedded retinal section ( 3 um thickness) was stained with H\&E) for histological examination. The stained region in the ONL layer was measured using metamorph (MetaMorph ${ }^{\circledR}$ Image Analysis Software Version 4.0, Universal Imaging Corp. Downingtown, PA, USA) and calculated using the following equation:

$$
\text { ONL nuclei area }(\%)=\left(\frac{\text { Stained area in ONL layer }}{\text { Total area of ONL }}\right) * 100 \text {. }
$$

\subsection{Statistical Analysis}

The results are presented as Mean \pm Standard Deviation (SD) $(n \geq 3)$. Statistical analysis was performed in the GraphPad Prism 5 software (GraphPad, San Diego, CA, USA). Differences in the mean values between groups were determined using one-way analysis of variance (ANOVA) followed by Tukey's honestly significant differences (HSD) test.

\section{Conclusions}

The present study provided evidence that ALE protects human ARPE-19 cells and BALB/c mice from A2E-induced and light-induced damages, respectively. ALE containing polyphenols (phenolic compounds and flavonoids) showed antioxidant and protective effects on A2E accumulation and A2E-induced cell death. In addition, ALE inhibited A2E-induced apoptosis by the suppression of caspase 3 cleavage and Bax, as well as the activation of Bcl-2. The inhibitory effect of ALE on dry AMD was confirmed by BALB/c mice. It was seen that the junction between cells in the ONL layer became stable against light exposure. Prevention is best for dry AMD with no symptoms. Therefore, food materials are a good natural source for the prevention of dry AMD. Our study suggests that the leaves of AL could be considered as potential medicine for preventing AMD.

Author Contributions: Conceptualization, M.J.K.; experiments, D.H.K. and Y.R.C.; data analysis, D.H.K. and Y.R.C.; writing—original draft preparation, D.H.K. and M.J.K.; writing—review and editing, J.S., Y.-S.C., Y.T.K., M.K.K., and M.J.K.; supervision, M.J.K.; project administration, M.J.K.; funding acquisition, M.J.K. All authors have read and agreed to the published version of the manuscript.

Funding: This research was funded by 2017 Ottogi Foundation research program and Main Research Program (E0164502-05) of the Korea Food Research Institute.

Acknowledgments: The authors would like to thank the financial support provided by Ottogi Foundation and KFRI.

Conflicts of Interest: All authors declare that there is no conflict of interest.

\section{References}

1. Wong, W.L.; Su, W.; Li, W.; Cheung, C.M.G.; Kelin, R.; Cheng, C.-Y.; Wong, T.Y. Global prevalence of age-related macular degeneration and disease burden projection for 2020 and 2040: A systematic review and meta-analysis. Lancet Glob. Health 2014, 2, e106-e116. [CrossRef]

2. Chen, Y.; Bedell, M.; Zhang, K. Age-related macular degeneration: Genetic and environmental factors of disease. Mol. Interv. 2010, 10, 271-281. [CrossRef] [PubMed]

3. Velilla, S.; García-Medina, J.J.; García-Layana, A.; Dolz-Marco, R.; Pons-Vázquez, S.; Pinazo-Durán, M.D.; Gómez-Ulla, F.; Arévalo, J.F.; Díaz-Llopis, M.; Gallego-Pinazo, R. Smoking and age-related macular degeneration: Review and update. J. Ophthalmol. 2013, 2013, 895147. [CrossRef] [PubMed]

4. Radu, R.A.; Mata, N.L.; Nusinowitz, S.; Liu, X.; Sieving, P.A.; Travis, G.H. Treatment with isotretinoin inhibits lipofuscin accumulation in a mouse model of recessive Stargardt's macular degeneration. Proc. Natl. Acad. Sci. USA 2003, 100, 4742-4747. [CrossRef] 
5. Vives-Bauza, C.; Anand, M.; Shirazi, A.K.; Magrane, J.; Gao, J.; Vollmer-Snarr, H.R.; Manfredi, G.; Finnemann, S.C. The age lipid A2E and mitochondrial dysfunction synergistically impair phagocytosis by retinal pigment epithelial cells. J. Biol. Chem. 2008, 283, 24770-24780. [CrossRef]

6. Kuse, Y.; Ogawa, K.; Tsuruma, K.; Shimazawa, M.; Hara, H. Damage of photoreceptor-derived cells in culture induced by light emitting diode-derived blue light. Sci. Rep. 2014, 4, 5223. [CrossRef]

7. BlasiakI, J.; Pawlowska, E.; Szczepanska, J.; Kaarniranta, K. Interplay between autophagy and the ubiquitin-proteasome system and its role in the pathogenesis of age-related macular degeneration. Int. J. Mol. Sci. 2019, 20, 210. [CrossRef]

8. Roberts, J.E.; Kukielczak, B.M.; Hu, D.-N.; Miller, D.S.; Bilski, P.; Sik, R.H.; Motten, A.G.; Chignell, C.F. The role of A2E in prevention or enhancement of light damage in human retinal pigment epithelial cells. Photochem. Photobiol. 2002, 75, 184-190. [CrossRef]

9. Del Priore, L.V.; Kuo, Y.H.; Tezel, T.H. Age-related changes in human RPE cell density and apoptosis proportion in situ. Invest. Ophthalmol. Vis. Sci. 2002, 43, 3312-3318.

10. Sparrow, J.R.; Vollmer-Snarr, H.R.; Zhou, J.; Jang, Y.P.; Jockusch, S.; Itagaki, Y.; Nakanishi, K. A2E-epoxides damage DNA in retinal pigment epithelial cells Vitamin E and other antioxidants inhibit A2E-epoxide formation. J. Biol. Chem. 2003, 278, 18207-18213. [CrossRef]

11. Sparrow, J.R.; Zhou, J.; Cai, B. DNA is a target of the photodynamic effects elicited in A2E-laden RPE by blue-light illumination. Invest. Ophth. Vis. Sci. 2003, 44, 2245-2251. [CrossRef] [PubMed]

12. Jung, B.S.; Shin, M.K. Encyclopedia of Illustrated Korean Natural Drugs; Young Lim Sa: Seoul, Korea, 1990; pp. 1010-1012.

13. Park, S.Y.; Hong, S.S.; Han, X.; Hwang, J.S.; Lee, D.; Ro, J.S.; Hwang, B.Y. Lignans from Arctium lappa and their inhibition of LPS-induced nitric oxide production. Chem. Pharm. Bull. 2007, 55, 150-152. [CrossRef] [PubMed]

14. Chan, Y.-S.; Cheng, L.-N.; Wu, J.-H.; Chan, E.; Kwan, Y.-W.; Lee, S.M.-Y.; Leung, G.P.-H.; Yu, P.H.-F.; Chan, S.-W. A review of the pharmacological effects of Arctium lappa (burdock). Inflammopharmacology 2011, 19, 245-254. [CrossRef] [PubMed]

15. Liu, J.; Cai, Y.Z.; Wong, R.N.; Lee, C.K.; Tang, S.C.; Sze, S.C.; Tong, Y.; Zhang, Y. Comparative analysis of caffeoylquinic acids and lignans in roots and seeds among various burdock (Arctium lappa) genotypes with high antioxidant activity. J. Agric. Food Chem. 2012, 60, 4067-4075. [CrossRef] [PubMed]

16. Lee, I.A.; Joh, E.H.; Kim, D.H. Arctigenin isolated from the seeds of Arctium lappa ameliorates memory deficits in mice. Planta Med. 2011, 77, 1525-1527. [CrossRef] [PubMed]

17. Yang, Y.N.; Huang, X.Y.; Feng, Z.M.; Jiang, J.S.; Zhang, P.C. Hepatoprotective activity of twelve novel 7'-hydroxy lignan glucosides from Arctii Fructus. J. Agric. Food Chem. 2014, 62, 9095-9102. [CrossRef]

18. Lou, Z. Effect of simultaneous ultrasonic/microwave assisted extraction on the antioxidant and antibacterial activities of burdock leaves. J. Med. Plants Res. 2011, 5, 5370-5377.

19. Tang, Y.; Lou, Z.; Yang, L.; Wang, H. Screening of antimicrobial compounds against Salmonellaty phimurium from burdock (Arctium lappa) leaf based on metabolomics. Eur. Food Res. Technol. 2015, 240, 1203-1209. [CrossRef]

20. Lou, Z.; Wang, H.; Zhu, S.; Chen, S.; Zhang, M.; Wang, Z. Ionic liquids based simultaneous ultrasonic and microwave assisted extraction of phenolic compounds from burdock leaves. Anal. Chim. Acta 2012, 716, 28-33. [CrossRef]

21. Machado, F.B.; Yamamoto, R.E.; Zanoli, K.; Nocchi, S.R.; Novello, C.R.; Schuquel, I.T.A.; Sakuragui, C.M.; Luftmann, H.; Ueda-Nakamura, T.; Nakamura, C.V. Evaluation of the antiproliferative activity of the leaves from Arctium lappa by a bioassay-guided fractionation. Molecules 2012, 17, 1852-1859. [CrossRef]

22. Pereira, J.V.; Bergamo, D.C.B.; Pereira, J.O.; França, S.d.C.; Pietro, R.C.L.R.; Silva-Sousa, Y.T.C. Antimicrobial activity of Arctium lappa constituents against microorganisms commonly found in endodontic infections. Braz. Dent. J. 2005, 16, 192-196. [CrossRef] [PubMed]

23. Lou, Z.; Wang, H.; Li, J.; Chen, S.; Zhu, S.; Ma, C.; Wang, Z. Antioxidant activity and chemical composition of the fractions from burdock leaves. J. Food Sci. 2010, 75, C413-C419. [CrossRef] [PubMed]

24. van Lookeren Campagne, M.; LeCouter, J.; Yaspan, B.L.; Ye, W. Mechanisms of age-related macular degeneration and therapeutic opportunities. J. Pathol. 2014, 232, 151-164. [CrossRef] [PubMed]

25. Ambati, J.; Fowler, B.J. Mechanisms of age-related macular degeneration. Neuron 2012, 75, 26-39. [CrossRef] 
26. Wang, L.; Clark, M.E.; Crossman, D.K.; Kojima, K.; Messinger, J.D.; Mobley, J.A.; Curcio, C.A. Abundant Lipid and Protein Components of Drusen. PLoS ONE 2010, 5, e10329. [CrossRef]

27. Mullins, R.F.; Russell, S.R.; Anderson, D.H.; Hageman, G.S. Drusen associated with aging and age-related macular degeneration contain proteins common to extracellular deposits associated with atherosclerosis, elastosis, amyloidosis, and dense deposit disease. FASEB J. 2000, 14, 835-846. [CrossRef]

28. Anderson, D.H.; Ozaki, S.; Nealon, M.; Neitz, J.; Mullins, R.F.; Hageman, G.S.; Johnson, L.V. Local cellular sources of apolipoprotein $\mathrm{E}$ in the human retina and retinal pigmented epithelium: Implications for the process of drusen formation. Am. J. Ophthalmol. 2001, 131, 767-781. [CrossRef]

29. Crabb, J.W.; Miyagi, M.; Gu, X.; Shadrach, K.; West, K.A.; Sakaguchi, H.; Kamei, M.; Hasan, A.; Yan, L.; Rayborn, M.E. Drusen proteome analysis: An approach to the etiology of age-related macular degeneration. Proc. Natl. Acad. Sci. USA 2002, 99, 14682-14687. [CrossRef]

30. Eldred, G.E.; Katz, M.I. The autofluorescent products of lipid peroxidation may not be lipofuscin-like. Free Radic. Biol. Med. 1989, 7, 157-163. [CrossRef]

31. Wu, Y.; Fishkin, N.E.; Pande, A.; Pande, J.; Sparrow, J.R. Novel lipofuscin bisretinoids prominent in human retina and in a model of recessive Stargardt disease. J. Biol. Chem. 2009, 284, 20155-20166. [CrossRef]

32. Jarrett, S.G.; Boulton, M.E. Consequences of oxidative stress in age-related macular degeneration. Mol. Aspects Med. 2012, 33, 399-417. [CrossRef] [PubMed]

33. Finnemann, S.C.; Leung, L.W.; Rodriguez-Boulan, E. The lipofuscin component A2E selectively inhibits phagolysosomal degradation of photoreceptor phospholipid by the retinal pigment epithelium. Proc. Natl. Acad. Sci. USA 2002, 99, 3842-3847. [CrossRef] [PubMed]

34. Sparrow, J.R.; Parish, C.A.; Hashimoto, M.; Nakanishi, K. A2E, a lipofuscin fluorophore, in human retinal pigmented epithelial cells in culture. Invest. Ophthalmol. Vis. Sci. 1999, 40, 2988-2995. [PubMed]

35. Parish, C.A.; Hashimoto, M.; Nakanishi, K.; Dillon, J.; Sparrow, J. Isolation and one-step preparation of A2E and iso-A2E, fluorophores from human retinal pigment epithelium. Proc. Natl. Acad. Sci. USA 1998, 95, 14609-14613. [CrossRef]

36. Zhang, J.; Bai, Y.; Huang, L.; Qi, Y.; Zhang, Q.; Li, S.; Wu, Y.; Li, X. Protective effect of autophagy on human retinal pigment epithelial cells against lipofuscin fluorophore A2E: Implications for age-related macular degeneration. Cell Death Dis. 2015, 6, e1972. [CrossRef]

37. Saadat, K.A.; Murakami, Y.; Tan, X.; Nomura, Y.; Yasukawa, T.; Okada, E.; Ikeda, Y.; Yanagi, Y. Inhibition of autophagy induces retinal pigment epithelial cell damage by the lipofuscin fluorophore A2E. FEBS Open Bio 2014, 4, 1007-1014. [CrossRef]

38. Ragauskaite, L.; Heckathorn, R.C.; Gaillard, E.R. Environmental Effects on the Photochemistry of A2-E, a Component of Human Retinal Lipofuscin. Photochem. Photobiol. 2001, 74, 483-488. [CrossRef]

39. Reszka, K.; Eldred, G.E.; Wang, R.-H.; Chignell, C.; Dillon, J. The photochemistry of human retinal lipofuscin as studied by EPR. Photochem. Photobiol. 1995, 62, 1005-1008. [CrossRef]

40. Lee, S.-O.; Lee, H.-J.; Yu, M.-H.; Im, H.-G.; Lee, I.-S. Total polyphenol contents and antioxidant activities of methanol extracts from vegetables produced in Ullung island. Kor. J. Food Sci. Technol. 2005, 37, 233-240.

41. Wang, Y.; Kim, H.J.; Sparrow, J.R. Quercetin and cyanidin-3-glucoside protect against photooxidation and photodegradation of A2E in retinal pigment epithelial cells. Exp. Eye Res. 2017, 160, 45-55. [CrossRef]

42. Pintea, A.; Rugină, D.; Pârlog, R.; Varga, A. Chlorogenic acid reduces oxidative stress in RPE cells. Bull. UASVM Vet. Med. 2009, 66, 220-225.

43. Chu, W.-K.; Cheung, S.C.; Lau, R.; Benzie, F.F. Bilberry (Vaccinium myrtillus L.). In Herbal Medicine: Biomolecular and Clinical Aspects, 2nd ed.; Benzie, I.F.F., Wachtel-Galor, S., Eds.; CRC Press/Taylor \& Francis: Boca Raton, FL, USA, 2011; pp. 55-72.

44. Bian, Q.; Gao, S.; Zhou, J.; Qin, J.; Taylor, A.; Johnson, E.J.; Tang, G.; Sparrow, J.R.; Gierhart, D.; Shang, F. Lutein and zeaxanthin supplementation reduces photooxidative damage and modulates the expression of inflammation-related genes in retinal pigment epithelial cells. Free Radic. Biol. Med. 2012, 53, 1298-1307. [CrossRef] [PubMed]

45. Yoon, S.-M.; Lee, B.-L.; Guo, Y.-R.; Choung, S.-Y. Preventive effect of Vaccinium uliginosum L. extract and its fractions on age-related macular degeneration and its action mechanisms. Arch. Pharm. Res. 2016, 39, $21-32$. [CrossRef] [PubMed]

46. Kim, J.; Cho, K.; Choung, S.-Y. Protective effect of Prunella vulgaris var. L extract against blue light induced damages in ARPE-19 cells and mouse retina. Free Radic. Biol. Med. 2019, in press. [CrossRef] [PubMed] 
47. Lee, B.-L.; Kang, J.-H.; Kim, H.-M.; Jeong, S.-H.; Jang, D.-S.; Jang, Y.-P.; Choung, S.-Y. Polyphenol-enriched Vaccinium uliginosum L. fractions reduce retinal damage induced by blue light in A2E-laden ARPE19 cell cultures and mice. Nutr. Res. 2016, 36, 1402-1414. [CrossRef]

48. Kettern, N.; Rogon, C.; Limmer, A.; Schild, H.; Höhfeld, J. The Hsc/Hsp70 co-chaperone network controls antigen aggregation and presentation during maturation of professional antigen presenting cells. PLoS ONE 2011, 6, e16398. [CrossRef]

49. Richter-Landsberg, C.; Leyk, J. Inclusion body formation, macroautophagy, and the role of HDAC6 in neurodegeneration. Acta Neuropathol. 2013, 126, 793-807. [CrossRef]

50. Seiberlich, V.; Borchert, J.; Zhukareva, V.; Richter-Landsberg, C. Inhibition of protein deubiquitination by PR-619 activates the autophagic pathway in OLN-t40 oligodendroglial cells. Cell Biochem. Biophys. 2013, 67, 149-160. [CrossRef]

51. Popovic, D.; Vucic, D.; Dikic, I. Ubiquitination in disease pathogenesis and treatment. Nat. Med. 2014, 20, 1242. [CrossRef]

52. Rodolfo, C.; Campello, S.; Cecconi, F. Mitophagy in neurodegenerative diseases. Neurochem. Int. 2018, 117, 156-166. [CrossRef]

53. Höhn, A.; Grune, T. Lipofuscin: Formation, effects and role of macroautophagy. Redox Biol. 2013, 1, $140-144$. [CrossRef] [PubMed]

54. Sitte, N.; Huber, M.; Grune, T.; Ladhoff, A.; Doecke, W.-D.; Von Zglinicki, T.; Davies, K.J. Proteasome inhibition by lipofuscin/ceroid during postmitotic aging of fibroblasts. FASEB J. 2000, 14, 1490-1498. [CrossRef] [PubMed]

55. Ryhänen, T.; Hyttinen, J.M.; Kopitz, J.; Rilla, K.; Kuusisto, E.; Mannermaa, E.; Viiri, J.; Holmberg, C.I.; Immonen, I.; Meri, S. Crosstalk between Hsp70 molecular chaperone, lysosomes and proteasomes in autophagy-mediated proteolysis in human retinal pigment epithelial cells. J. Cell. Mol. Med. 2009, 13, 3616-3631. [CrossRef] [PubMed]

56. Höhn, A.; Jung, T.; Grimm, S.; Catalgol, B.; Weber, D.; Grune, T. Lipofuscin inhibits the proteasome by binding to surface motifs. Free Radic. Biol. Med. 2011, 50, 585-591. [CrossRef]

57. Powell, S.R.; Wang, P.; Divald, A.; Teichberg, S.; Haridas, V.; McCloskey, T.W.; Davies, K.J.; Katzeff, H. Aggregates of oxidized proteins (lipofuscin) induce apoptosis through proteasome inhibition and dysregulation of proapoptotic proteins. Free Radic. Biol. Med. 2005, 38, 1093-1101. [CrossRef]

58. Shibagaki, K.; Okamoto, K.; Katsuta, O.; Nakamura, M. Beneficial protective effect of pramipexole on light-induced retinal damage in mice. Exp. Eye Res. 2015, 139, 64-72. [CrossRef]

59. Ratnayaka, J.A.; Lotery, A.J. Challenges in studying geographic atrophy (GA) age-related macular degeneration: The potential of a new mouse model with GA-like features. Neural Regen. Res. 2020, 15, 863-864. [CrossRef]

60. Fletcher, E.L.; Jobling, A.I.; Greferath, U.; Mills, S.A.; Waugh, M.; Ho, T.; de Iongh, R.U.; Phipps, J.A.; Vessey, K.A. Studying age-related macular degeneration using animal models. Optom. Vis. Sci. 2014, 91, 878-886. [CrossRef]

61. Park, S.-I.; Lee, E.H.; Kim, S.R.; Jang, Y.P. Anti-apoptotic Effects of Curcuma Longa L. Extract and Its Curcuminoids Against Blue Light-Induced Cytotoxicity in A2E-laden Human Retinal Pigment Epithelial Cells. J. Pharm. Pharmacol. 2017, 69, 334-340. [CrossRef]

62. Pisoschi, A.M.; Negulescu, G.P. Methods for Total Antioxidant Activity Determination: A Review. Anal. Biochem. 2011, 1, 1-10. [CrossRef]

63. Baba, S.A.; Malik, S.A. Determination of total phenolic and flavonoid content, antimicrobial and antioxidant activity of a root extract of Arisaema jacquemontii Blume. Integr. Med. Res. 2015, 9, 449-454. [CrossRef]

C 2020 by the authors. Licensee MDPI, Basel, Switzerland. This article is an open access article distributed under the terms and conditions of the Creative Commons Attribution (CC BY) license (http://creativecommons.org/licenses/by/4.0/). 